\title{
Multiple gene targeting siRNAs for down regulation of Immediate Early-2 (le2) and DNA polymerase genes mediated inhibition of novel rat Cytomegalovirus (strain All-03)
}

Krishnan Nair Balakrishnan', Ashwaq Ahmed Abdullah², Jamilu Abubakar Bala ${ }^{3}$, Faez Firdaus Abdullah Jesse ${ }^{4}$, Che Azurahanim Che Abdullah ${ }^{5}$, Mustapha Mohamed Noordin ${ }^{1}$ and Mohd Lila Mohd-Azmi ${ }^{* *}$

\begin{abstract}
Background: Cytomegalovirus (CMV) is an opportunistic pathogen that causes severe complications in congenitally infected newborns and non-immunocompetent individuals. Developing an effective vaccine is a major public health priority and current drugs are fronting resistance and side effects on recipients. In the present study, with the aim of exploring new strategies to counteract CMV replication, several anti-CMV siRNAs targeting IE2 and DNA polymerase gene regions were characterized and used as in combinations for antiviral therapy.

Methods: The rat embryo fibroblast (REF) cells were transfected with multi siRNA before infecting with CMV strain ALL-03. Viral growth inhibition was measured by tissue culture infectious dose (TCID50), cytopathic effect (CPE) and droplet digital PCR (ddPCR) while IE2 and DNA polymerase gene knockdown was determined by real-time PCR. Ganciclovir was deployed as a control to benchmark the efficacy of antiviral activities of respective individual siRNAs.

Results: There was no significant cytotoxicity encountered for all the combinations of siRNAs on REF cells analyzed by MTT colorimetric assay $(P>0.05)$. Cytopathic effects (CPE) in cells infected by RCMV ALL-03 had developed significantly less and at much slower rate compared to control group. The expression of targeted genes was downregulated successfully resulted in significant reduction $(P<0.05)$ of viral mRNA and DNA copies (dpb $+\mathrm{dpc}: 79 \%, 68 \%$; $\mathrm{dpb}+\mathrm{ie} 2 \mathrm{~b}: 68 \%, 60 \% ; \mathrm{dpb}+\mathrm{dpc}+\mathrm{ie} 2 \mathrm{~b}: 48 \%, 42 \%)$. Flow cytometry analysis showed a greater percentage of viable and early apoptosis of combined siRNAs-treated cells compared to control group. Notably, the siRNAs targeting gene regions were sequenced and mutations were not encountered, thereby avoiding the formation of mutant with potential resistant viruses.
\end{abstract}

Conclusions: In conclusion. The study demonstrated a tremendous promise of innovative approach with the deployment of combined siRNAs targeting at several genes simultaneously with the aim to control CMV replication in host cells.

Keywords: Cytomegalovirus, Combinations, Small interfering RNA, Replication, Gene expression

*Correspondence: azmi@upm.edu.my; azmilila@gmail.com

1 Department of Pathology and Microbiology, Faculty of Veterinary Medicine, University Putra Malaysia, Selangor, Malaysia

Full list of author information is available at the end of the article

\section{Introduction}

CMV often considerate as silent public health burden usually does not produce any symptoms after the infection. The prime reason was due to the ability of the virus to enter asymptomatic infection, once the virus replication was controlled by the host immune system $[1,2]$.

c) The Author(s) 2020. This article is licensed under a Creative Commons Attribution 4.0 International License, which permits use, sharing, adaptation, distribution and reproduction in any medium or format, as long as you give appropriate credit to the original author(s) and the source, provide a link to the Creative Commons licence, and indicate if changes were made. The images or other third party material in this article are included in the article's Creative Commons licence, unless indicated otherwise in a credit line to the material. If material is not included in the article's Creative Commons licence and your intended use is not permitted by statutory regulation or exceeds the permitted use, you will need to obtain permission directly from the copyright holder. To view a copy of this licence, visit http://creativecommons.org/licenses/by/4.0/. The Creative Commons Public Domain Dedication waiver (http://creativecommons.org/publicdomain/zero/1.0/) applies to the data made available in this article, unless otherwise stated in a credit line to the data. 
However, CMV can cause life-threatening condition in immunocompromised patients whom undergo transplant procedures, individuals diagnosed with AIDS and injured with third degree burn and elderly people to some extent [3-5]. Sadly, immature immune system of unborn child is prone to CMV infection causing complications such as microcephaly, mental retardation and hearing loss $[6,7]$. The term RNAi is generally understood as a mean of evolutionary conserved mechanism during post-transcriptional silencing triggered by double stranded RNAs, in wide range of eukaryotic organisms. This system was initially discovered in nematode Caenorhabditis elegans [8]. Slowly, the usage of RNAi turned to be a broader wave of advance which has been employed as a treatment method for many infectious diseases, cancerous and nerve dysfunction disorders [9-15]. Introducing synthetic 21-23 nucleotides of siRNA could specifically inhibit the cellular mRNA in order to control the gene expression [16]. Up to date, various studies have been reported that delivering siRNA, to inhibit the viral replication and gene expression of growing number of human infectious viruses were promising $[12,17]$. It was suggested that a greater focus on siRNA could produce interesting findings that account more for the siRNA utilization as antiviral strategy for future therapeutics. Growing research work proves that RNAi can inhibit or suppress most of the viruses despite RNA or DNA and whether single or double stranded structure. Combination of RNAi targeting different conserved regions is expected to function efficiently in reducing the chances of viral escape. For instance, in other mono-therapies, sequence specific RNAi facing problem where the virus escapes due to the mutant in target region resulting in growth of viral mutant [18-20]. This statement validated by few studies such as polio, HIV and HCV where the viral activity of single siRNA reported to decrease in efficiency [19-21]. Viruses evolve to escape from host RNAi by encoding "suppressors of RNAi silencing" (SRS) which is another disadvantage of single use of siRNA. SiRNA cocktail targeting different region of viral genome lowers the chances of viral mutant formation and prevent viral escape [22-25]. Nevertheless, besides virus infections, siRNAs can be utilized to silence multiple genes at a time which could benefit in treating brain tumorigenesis involving multiple genetic alterations and also targeting a suitable apoptotic gene as a treatment [26, 27]. In addition, the availability to maintain the wide array of cells including islets of Langerhans could provide a strong foundation to use siRNAs for diabetic studies [28, 29]. Therefore, exploring combinations of siRNAs as a potential therapeutic approach for Malaysia CMV isolate has gear up for the treatment destination [30]. Interestingly, this local strain (RCMV ALL-03) has been identified crossing the placenta infecting the pups making it suitable for congenital infection on animal model [31]. The availability of the complete genome sequence of this virus add on more advantages for pathogenicity study and antiviral development [32,33]. Therefore, this study was conducted to screen combinations of siRNA for their effectiveness on inhibiting RCMV ALL-03 virus replication and gene expression.

\section{Material and methods \\ Selection of siRNA combinations}

The siRNA combinations were selected based on the successive percentage of individual siRNA inhibiting RCMV ALL-03 replication and gene expression (data not shown). The tested siRNA combinations were $d p b+d p c$, $\mathrm{dpb}+\mathrm{ie} 2 \mathrm{~b}, \mathrm{dpc}+\mathrm{ie} 2 \mathrm{~b}$ and $\mathrm{dpb}+\mathrm{dpc}+\mathrm{ie} 2 \mathrm{~b}$ where $\mathrm{dpb}$ and dpc siRNAs targeting DNA polymerase region while ie2b targeting Immediate early 2 region. The sequences of designed siRNAs were displayed in Table 1.

\section{Cell culture, transfection and virus infection}

Rat embryo fibroblast cells were propagated in 10\% fetal bovine serum supplemented with DMEM nutrient solution. The cells were maintained with at $5 \% \mathrm{CO}_{2}$ and $37{ }^{\circ} \mathrm{C}$ in an incubator. Prior to siRNA transfection, the cells were seeded on 6 well plates to achieve $70-80 \%$ of confluency level. After $24 \mathrm{~h}$, combination siRNAs were

Table 1 Sequence of RCMV ALL-03 specific siRNAs and their location within the genome (Accession number KP967684.1)

\begin{tabular}{lll}
\hline siRnA & Sequence $\left(\mathbf{5}^{\prime} \rightarrow \mathbf{3}^{\prime}\right)$ & \\
\cline { 2 - 3 } & Sense & Antisense \\
\hline ie2b & CCGAAGCACUGGACAAGUAtt & UACUUGUCCAGUGCUUCGGat \\
$\mathrm{dpb}$ & CUAUAAGGGUAGAAUAACAAtt & UGUUAUUCUACCCUUAUAGtg \\
$\mathrm{dpc}$ & GCCUGAUCGUACGUAUGAAtt & UUCAUACGUACGAUCAGGCtg \\
Negative control & UUCUCCGACGUGUCACGUtt & ACGUGACACGUUCGGAGAAtt
\end{tabular}

Sequence of the scrambled siRNA (negative control) used in this study was included below

NA not applicable 
transfected together with lipofectamine 3000 transfection reagent $(1.5 \mu \mathrm{l} /$ well). In each well, siRNAs were mixed to produce a final concentration of $300 \mathrm{pmol} / \mathrm{well}$. Appropriate controls for treatment and non-treatment were included as well followed by twenty-four hours of incubation. Meanwhile, during the incubation, DMEM media without antibiotic was replaced at $6 \mathrm{~h}$ post transfection to avoid any contamination. Next, cells were infected with RCMV ALL-03 isolated from uterus and placenta of rats [30] at MOI of 1 . The plates were incubated for $1 \mathrm{~h}$ and then the cells were washed with cold PBS followed by addition of fresh DMEM medium supplemented with $10 \%$ serum. The cells were then monitored continuously for CPE occurrence and the cultured cells were collected for all the analysis at appropriate time points. Ganciclovir was used as positive control and scramble siRNA as negative control for treatment groups while untreated cells as positive control and uninfected cells as negative control for non-treatment groups. Each siRNA combination was duplicated and was performed twice independently.

\section{Cellular viability assay}

Cells with optimized density, $1 \times 10^{5}$ were seeded in 96 wells plate supplemented with DMEM media with $10 \%$ FBS. The cells were incubated at $37{ }^{\circ} \mathrm{C}$ for $24 \mathrm{~h}$. Once the cells are established for the treatment, the media was discarded, and the confluent cells were washed with cold PBS. The combination siRNAs was transfected and incubated at $37{ }^{\circ} \mathrm{C}$ without the infection of the virus. The plates were removed from incubator at 24,48 and $72 \mathrm{~h}$ of time interval. Then, MTT assay was carried out to identify the cell viability. All the cells were washed twice with PBS followed by addition of $(5 \mathrm{mg} / \mathrm{ml})$ MTT (tetrazolium dye, 3-[4,5-dimethylthiazol-2-yl]-2,5-diphenyltetrazolium bromide) reagent and incubated for $4 \mathrm{~h}$ at $37^{\circ} \mathrm{C}$. The MTT addition procedure was taken place in dark area and the plate was covered with aluminium foil during the $4 \mathrm{~h}$ incubation due to the sensitivity of MTT towards light. Later on, the MTT reagent was discarded carefully, and $200 \mu \mathrm{l}$ of dimethyl sulfoxide was added to each well. Then, the plate was covered again with aluminium foil and leave for $20 \mathrm{~min}$ at room temperature. This is to make sure the formazon dye crystals to dissolve completely into purple color. Lastly, the results were obtained from the measured absorbance at $570 \mathrm{~nm}$ using a spectrophotometer microplate reader. Each assay was performed in triplicates and the cytotoxicity was calculated from an average of 3 replicates. The final results are presented as mean \pm standard deviation.

\section{Titration of effective combination siRNAs via TCID 50}

TCID50 was conducted to investigate the effects of combination siRNAs on controlling RCMV ALL-03 titer at different time intervals of post infection (day 10 and 18). Following the transfection of combination siRNAs, the REF monolayers were infected with MOI 1 RCMV ALL03. TCID50 of each combination siRNAs transfected samples were analyzed and compared with TCID50 of non-transfected virus control group as previously reported [34]. All treatments were performed in triplicate and the results were expressed as mean $\pm \mathrm{SE}$.

\section{Apoptosis analysis by flow cytometry}

Flow cytometry technique was employed to evaluate the percentage of viable cells, early apoptosis cells; late apoptosis cells and necrotic cells of combinations siRNA treated and control groups. The samples were prepared by Annexin V-FITC Apoptosis Detection Kit (Nacalai Tesque, Japan). First, the cells were washed twice using cold PBS followed by trypsinization to detach the cells from the culture plates. Briefly, $1 \times 10^{6}$ cells $/ \mathrm{ml}$ were resuspended in Annexin V Binding Solution $(1 \times)$. Then, the $100 \mu \mathrm{l}$ of suspension cells were incubated with $5 \mu \mathrm{L}$ of Annexin V-FITC Conjugate and $5 \mu \mathrm{l}$ of Propidium Iodide (PI) at room temperature. After $15 \mathrm{~min}, 400 \mu \mathrm{l}$ of Annexin V Binding Solution $(1 \times)$ was added to the sample solution and were analyzed with a FACSCalibur flow cytometer (BD, Bioscience, USA).

\section{Droplet digital PCR}

Droplet digital PCR is an emerging third generation of nucleic acid detection methodology gaining an interest for absolute quantification of any target sequence without the needs of standard curve. Before the commencement of ddPCR experiment, primers and probe were designed targeting DNA poly region and were synthesized by IDT technologies following standard procedures. Selected primer sequences were CCGAAGTACCAGATTCAA (forward primer), GACGAGAGGGAGTATATT (reverse primer) and FAM-CGGACGGTGAACTCGTTTTTTAMRA (Taqman probe). The experiment began with the preparation of reaction mix at $11 \mu \mathrm{l}$ per reaction. After that, $1.98 \mu \mathrm{l}$ of each forward and reverse primers are added into the reaction mix followed by $0.55 \mu \mathrm{l}$ of probe. The samples were labelled as shown in Table 2. Then, $5.49 \mu \mathrm{l}$ of DNase-free water was added. All components were then mixed up properly by pipetting up and down. Equally aliquot which was $21 \mu \mathrm{l}$ were dispensed into each reaction tube. Then, $1 \mu \mathrm{l}$ of DNA sample are added accordingly into the PCR tubes. The reaction were again mixed properly and be allowed to be equilibrated at room temperature for about $3 \mathrm{~min}$. Once the reaction mixtures were ready, $20 \mu \mathrm{l}$ of the PCR reaction mixture were then loaded into the sample well of a DG8 ${ }^{\mathrm{TM}}$ Cartridge as well as $70 \mu \mathrm{l}$ of Droplet Generation Oil into the oil wells. The cartridge loaded with sample was placed 
Table 2 Samples used in ddPCR setup

\begin{tabular}{ll}
\hline Labelling of the sample & Type of siRNAs sample \\
\hline Sample 1 & $d p b+d p c$ \\
Sample 2 & $d p b+i e 2 b$ \\
Sample 3 & $d p c+i e 2 b$ \\
Sample 4 & $d p b+d p c+i e 2 b$ \\
Sample 5 & GCV \\
Sample 6 & Negative control \\
Sample 7 & Untreated \\
Sample 8 & Uninfected \\
\hline
\end{tabular}

inside the $\mathrm{Q} \times 200$ Droplet Generator to partition the sample hence generating the droplet for $2 \mathrm{~min}$. Then, the obtained droplets were carefully transferred into a clean 96-well plate. The plate was then sealed with foil by using the $\mathrm{P} \times 1$ PCR Plate Sealer. PCR thermal cycling was then proceeded, and the sealed 96-well plate was placed in the $\mathrm{Q} \times 200$ Droplet Reader in order to detect the positive and negative droplets. QuantaSoft ${ }^{\mathrm{TM}}$ Software was used to analyze the obtained results.

\section{Cytopathic effect rate of RCMV ALL-03}

The replication of virus can be identified indirectly by physical appearance changes of normal cells. It is also known as cytopathic effect (CPE) monitoring. In order to determine the efficacy of combination siRNAs, the transfected wells were monitored for virus induced CPE out to 18 days post infection by a using Nikon Eclipse TS100 Inverted Microscope (Nikon Instruments, Inc., New York, USA). All the images of combination siRNAs transfected as well other control groups were compared and recorded.

\section{Real time RT-PCR for treated samples}

Gene expression study of combination siRNAs treated samples were carried out using optimized custom designed Taqman probes via CFX96TM real time PCR detection system (Bio-Rad, USA). Since combination siRNAs having two different gene targets: IE2 and DNA poly, each combination siRNAs were analyzed for both genes' expression. All the primers and probes have been optimized and appropriate standard curve have been generated (Additional file 1: Figure S1). RCMV ALL03 mRNA was extracted from the control and siRNA treated samples following manufacturer instruction by using a GENEzol ${ }^{\mathrm{TM}}$ TriRNA Pure kit (Geneaid, UK) with slight modifications. The RNA was finally eluted in $30 \mu \mathrm{l}$ of RNase-free water and was maintained on $-70{ }^{\circ} \mathrm{C}$ for further analysis. The quantity and quality of extracted RNA were assessed by spectrophotometry
Table 3 Primers and probe sequences used for real-time PCR assay

\begin{tabular}{lll}
\hline Target & Primer sequence & $\begin{array}{l}\text { Product } \\
\text { size (bp) }\end{array}$ \\
\hline GAPDH & tctccaccactatcgcagaa & 100 \\
Forward & ttggcagcttggactatgct & \\
Reverse & FAM-tccgttttggcagagaagatgcaa-TAMRA & \\
Probe & & 256 \\
ie2b & gcgattttgatctacgtg & \\
Forward & acagcgaacctatagaca & \\
Reverse & FAM-caacggggggaggaaacaga-TAMRA & 100 \\
Probe & & \\
dpb & aggacatcatcacgagaa \\
Forward & tcaaacaaagatagcggg \\
Reverse & FAM-agatcggtggggtatcagg-TAMRA & \\
Probe & & \\
$\begin{array}{l}\text { dpc } \\
\text { Forward }\end{array}$ & ccgaagtaccagattcaa \\
Reverse & gacgagagggagtatatt \\
Probe & FAM-cggacggtgaactcgtttt-TAMRA & \\
\hline
\end{tabular}

using the Nanodrop 1000 spectrophotometer (Thermo Scientific $\left.^{\mathrm{TM}}\right)$. Next, complementary DNA was synthesized using Tetro cDNA synthesis kit (Bioline, UK) on thermal cycler (BioRad, USA) following manufacturer's instructions. The prepared cDNA was stored at $-20{ }^{\circ} \mathrm{C}$ for subsequent analysis. Finally, gene expression study of combinations siRNAs treated samples were carried out using designed Taqman probes via CFX $96^{\mathrm{TM}}$ real time PCR detection system (Bio-Rad, USA). Specific primers and probe were used for each siRNA region as depicted in Table 3. To normalize the expression analysis, Glyceraldehyde 3-phosphate dehydrogenase (GAPDH) was used as housekeeping gene which served as internal control to quantify the mRNA expression in all the combination siRNAs treated and non-treated samples. The reaction was set up with cDNA as template with $400 \mathrm{nM}$ concentration of each specific forward and reverse primers, $100 \mathrm{nM}$ of probe, $1 \times$ SensiFast probe Hi-Rox mix and appropriate nuclease free water. The cycling conditions was followed as for standard curve generation (data not shown) Mean quantitative cycle values (cq) were obtained from the triplicates and recorded using BioRad, CFX manager software version 3.0 (Bio-Rad, USA).

\section{Data analysis for quantification of gene expression}

Four combination siRNAs: $d p b+d p c, d p b+i e 2 b$, $\mathrm{dpc}+\mathrm{ie} 2 \mathrm{~b}$ and $\mathrm{dpb}+\mathrm{dpc}+\mathrm{ie} 2 \mathrm{~b}$ were assessed for their effectiveness on inhibiting the IE2 and DNA poly gene expression of RCMV ALL-03. The relative fold change of the genes treated with siRNA were compared with 
untreated control group and the relative fold changes were calculated using $-\Delta \Delta C T$ method. Bio-Rad, CFX manager software version 3.0 (Bio-Rad, USA) was used for the normalization of target region with house-keeping gene GAPDH and quantification of fold changes were calculated as described previously [35].

\section{Calculating knockdown efficiencies}

The percentage of knockdown efficiency was calculated following $-\Delta \Delta C T$ method with slight modification [36]. The levels of siRNA treated target expression was normalized to non-target GAPDH as reference gene (REF) within the same sample as equation below:

$$
\Delta \mathrm{Ct}=\mathrm{Ct}_{(\text {Target })}-\mathrm{Ct}_{(\mathrm{REF})}
$$

Next, the $\Delta \mathrm{Ct}$ for each biologically replicate was transformed exponentially to the $\Delta \mathrm{Ct}$ expression followed by determining the standard deviation. The equation as follows:

$$
\Delta \mathrm{Ct} \text { expression }=2^{-\Delta \mathrm{Ct}}
$$

Then, the mean was normalized to the expression of siRNA treated sample with non-targeting siRNA sample to find $\Delta \mathrm{Ct}$ expression level. Percentage of knockdown was calculated as equation below:

$\%$ Knock down $=\left(1-\Delta \Delta \mathrm{Ct}_{(\text {normalized expression })}\right) \times 100$

\section{Resistance of RCMV ALL-03 to siRNA combination treatment}

Drug resistances are important issue to be addressed where virus has the capability of developing it. In this combination treatment, the ability of RCMV ALL-03 to develop drug resistance via mutation occurrence in target regions was investigated. After the siRNA combination transfection, RCMV ALL-03 was infected and the extracellular progeny virus was harvested after 14 days pi. The harvested virus was used to re-infect the REF cells after being transfected again with siRNA combinations. After 14 days pi, the virus was harvested, and this method was repeated up to 5 infections. The final harvested virus was subjected for nucleic acid extraction together with stock of virus. Upon confirmation, the PCR products were sent for sequencing and the obtained results were compared for sequence identity using Clustal Omega online software.

\section{Statistical analysis}

All statistical analyses were performed using GraphPad Prism version 6 (GraphPad Software, USA). P values $<0.05$ were considered significant. Results are expressed as mean $\pm S D$ from a representative experiment performed in triplicate.

\section{Results}

Effects of combination siRNAs on cell viability

Combinations of siRNAs were subjected for cell viability assay using MTT cell proliferation method. Cytotoxicity analyses of tested siRNA combinations demonstrated that cell viability was almost unaffected at an optimized concentration of $300 \mathrm{pmol}$ at different time points. However, the triple combinations $\mathrm{dpb}+\mathrm{dpc}+\mathrm{ie} 2 \mathrm{~b}$ exhibit $50 \%$ toxicity level at 48 and $72 \mathrm{~h}$ for $300 \mathrm{pmol}$. On the other hand, all the double siRNA combinations such as $\mathrm{dpb}+\mathrm{dpc}, \mathrm{dpb}+\mathrm{ie} 2 \mathrm{~b}$ and $\mathrm{dpc}+\mathrm{ie} 2 \mathrm{~b}$ showed more than $70 \%$ of cell viability at highest concentration 300 pmol (Additional file 1: Figure S2).

\section{Small interfering RNAs inhibit virus growth}

RCMV ALL-03 was silenced with double or triple combinations and the virus titers were quantified by TCID50. The reading of viral titer was recorded at two different days: 10 and 18 (Fig. 1). This is because no significant viral load was detected at day 10 and maximum growth of virus could be achieved at day 18 (Fig. 1). Overall, different combinations siRNA showed different level of virus inhibiting capacity which siRNAs targeting DNA polymerase showed better RCMV ALL-03 inhibition rate. Administration of the siRNAs before RCMV ALL03 prevented the progression of the infection, since virus titers did not increase exponentially from day 10 pi to day 18 pi. By contrast, virus titers increased significantly from day 10 pi to day 18 pi in negative control siRNA and untreated groups. For instance, $\mathrm{dpb}+\mathrm{dpc}$ (2.5 $\left.\log _{10} \mathrm{TCID} 50 / \mathrm{ml}, 3.8 \log _{10} \mathrm{TCID} 50 / \mathrm{ml}\right)$ showed better viral inhibition rate at day 10 and 18, respectively followed by $\mathrm{dpb}+\mathrm{ie} 2 \mathrm{~b}\left(3.2 \log _{10}\right.$ TCID50/ml, 5 $\left.\log _{10} \mathrm{TCID} 50 / \mathrm{ml}\right)$ and $\mathrm{dpc}+\mathrm{ie} 2 \mathrm{~b}\left(3.2 \log _{10} \mathrm{TCID} 50 / \mathrm{ml}\right.$, $5.1 \log _{10}$ TCID50/ml). All these combinations had similar viral titer compared to positive control ganciclovir $3.2 \log _{10}$ TCID50/ml at day 10 p.i and $4.9 \log _{10}$ TCID50/ $\mathrm{ml}$ at day $18 \mathrm{p} . \mathrm{i}$. Therefore, the differences among the siRNA treated and ganciclovir are insignificant $(P>0.05)$. However, triple combinations $\mathrm{dpb}+\mathrm{dpc}+\mathrm{ie} 2 \mathrm{~b}$ $\log _{10}$ TCID50/ml, $5.9 \log _{10}$ TCID50/ml) displayed a lowest rate of viral inhibition compared to other combinations and GCV at both day 10 and 18. On the other hand, negative control siRNA and untreated groups showed higher viral titer than siRNA treated groups: $4 \log _{10}$ TCID50/ml at day 10 p.i and $8 \log _{10}$ TCID50/ml at day 18 p.i.

\section{Annexin V apoptosis study by flow cytometry}

Analysis of RCMV ALL-03 infected cells undergoing apoptosis/necrosis upon combination siRNAs 


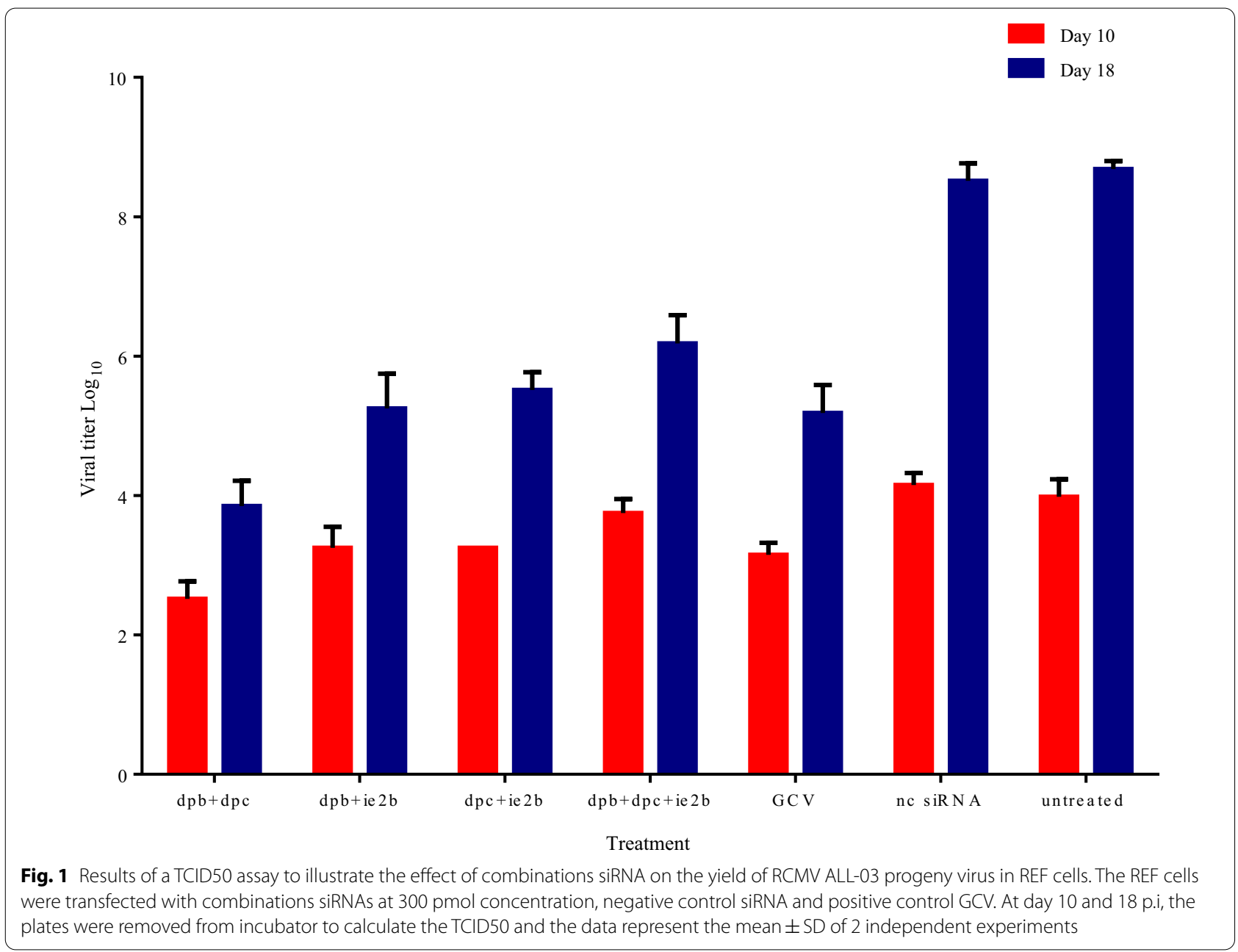

treatment were studied using flow cytometry. Dot plot view illustration was used to interpret the results of REF cells (Additional file 1: Figure S3). As revealed in Fig. 2, the percentages of viable cells are lesser compared to early apoptotic cells for all the siRNAs and GCV treated groups. Compared to untreated control group, $\mathrm{dpb}+\mathrm{dpc}$ has significant number of viable cells and early apoptotic cells $13.6 \% \pm 0.23$ and $31.2 \% \pm 0.17$ respectively. The significant number of cells recorded in early apoptotic were all the combination siRNAs and GCV treated group where $\mathrm{dpb}+\mathrm{ie} 2 \mathrm{~b}$ having the highest early apoptotic cells $(53.4 \% \pm 3.52)$. In addition, all the siRNAs and GCV treated groups showed least number of late apoptotic cells compared negative control siRNA and untreated groups. Meanwhile, lesser cells $(0.1-2 \%)$ were observed for necrotic phase for all the treated groups including the control groups.

\section{Viral DNA particles quantification by DDPCR Quantification of DNA copies/ $\mu \mathrm{l}$}

The quantification of RCMV ALL-03 DNA copies were presented per $\mu \mathrm{l}$ in the 100 -fold diluted sample. Therefore, the total viral DNA copies/ $\mu$ l from stock template was calculated and presented in Table 4. Visualization of ddPCR analysis plot having positive and negative droplets were screened prior to viral DNA quantification (Additional file 1: Figure S4). The final results have revealed that out of four combination siRNAs, $d p b+d p c$ has tremendously reduced the viral titre with 6,400 DNA copies $/ \mu \mathrm{l}$ with $68 \%$ of reduction compared to untreated control group having 20,200 DNA copies/ $\mu$ l. As expected, both of these siRNAs targeting DNA polymerase gene region showed better viral inhibition rate compared to combination siRNAs targeting IE2 gene region. Next, $\mathrm{dpb}+\mathrm{ie} 2 \mathrm{~b}$ followed by $\mathrm{dpb}+\mathrm{dpc}+\mathrm{ie} 2 \mathrm{~b}$ limits the virus 


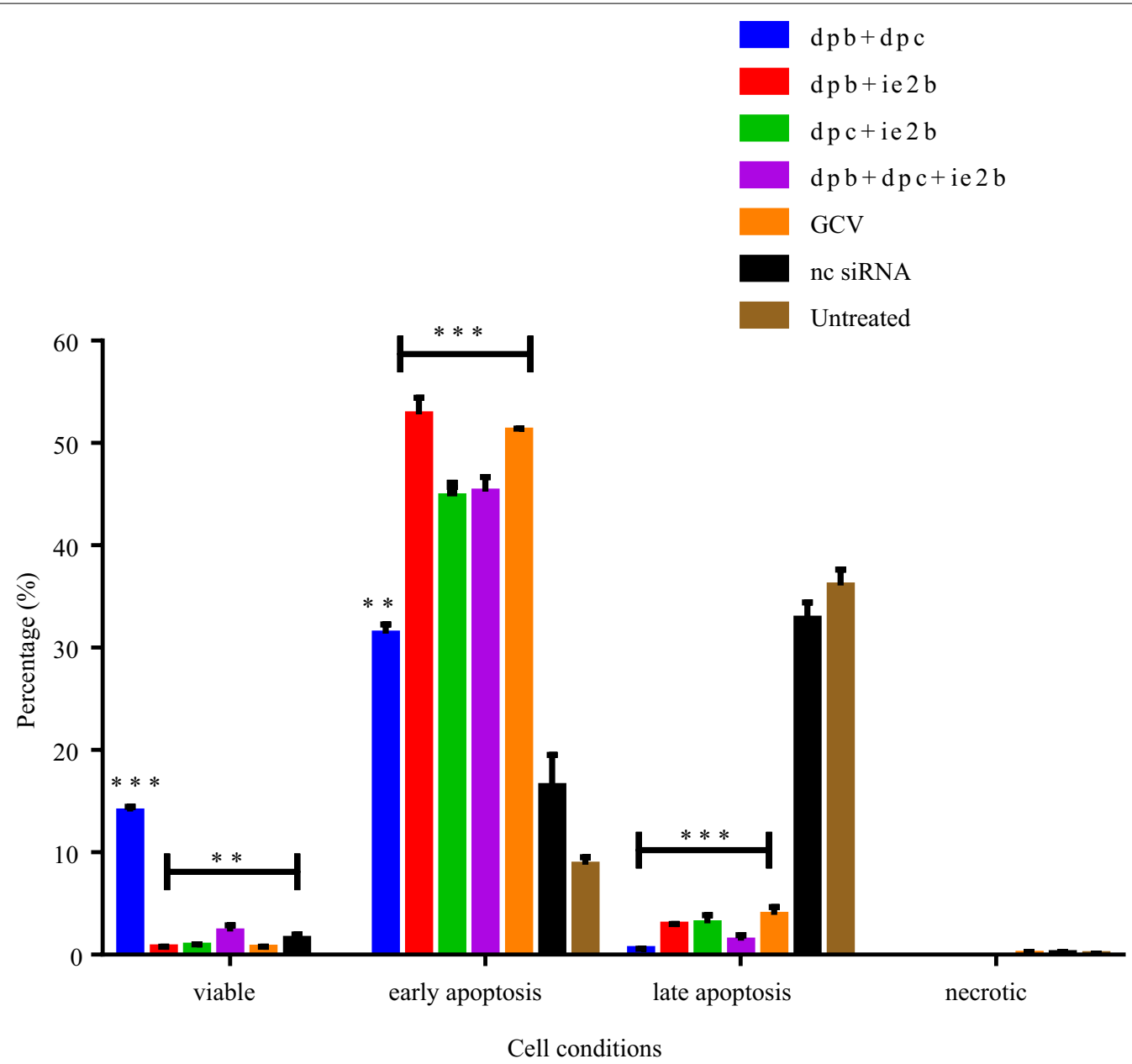

Fig. 2 Percentage of various distribution of REF cell conditions. The percentage of viable, early apoptotic, late apoptotic and necrotic cells were analysed for all the siRNA treated group. Each data point represents the mean of three independent experiments \pm SD. *Significantly different from the control $(P<0.05)$

Table 4 Total amount of DNA copies in stock template

\begin{tabular}{lcccc}
\hline Sample & $\begin{array}{l}\text { Viral DNA copies } \\
\text { in ddPCR mixture }\end{array}$ & $\begin{array}{l}\text { Viral DNA copies per } \boldsymbol{\mu l}(\mathbf{1 0 0} \\
\text { fold diluted })\end{array}$ & $\begin{array}{l}\text { Total viral DNA copies/ } \boldsymbol{\mu l} \\
\text { from stock template }\end{array}$ & $\begin{array}{l}\text { Percentage of viral } \\
\text { DNA copies reduction } \\
\text { (\%) }\end{array}$ \\
\hline $\mathrm{dpb}+\mathrm{dpc}$ & 3.2 & 64 & 6400 & 68 \\
$\mathrm{dpb}+\mathrm{ie} 2 \mathrm{~b}$ & 4 & 80 & 8000 & 60 \\
$\mathrm{dpc}+\mathrm{ie} 2 \mathrm{~b}$ & 8.8 & 176 & 17,600 & 13 \\
$\mathrm{dpb}+\mathrm{dpc}+\mathrm{ie} 2 \mathrm{~b}$ & 5.9 & 118 & 11,800 & 42 \\
$\mathrm{gcv}$ & 6.1 & 122 & 12,200 & 40 \\
nc siRnA & 9 & 180 & 18,000 & 10 \\
Untreated & 10.1 & 202 & 20,200 & 0 \\
Uninfected & 0 & 0 & 0 & 0 \\
\hline
\end{tabular}

particles with $60 \%$ and $42 \%$ rate effectiveness respectively (Fig. 3). However, dpc + ie $2 b$ showed to have the least effectivity rate $13 \%$ with 17,600 DNA copies/ $\mu$ l.
In comparison with other siRNA treated groups, commercial drug GCV treatment was found to be median effective rate in reducing the viral DNA copies $(12,200$ 


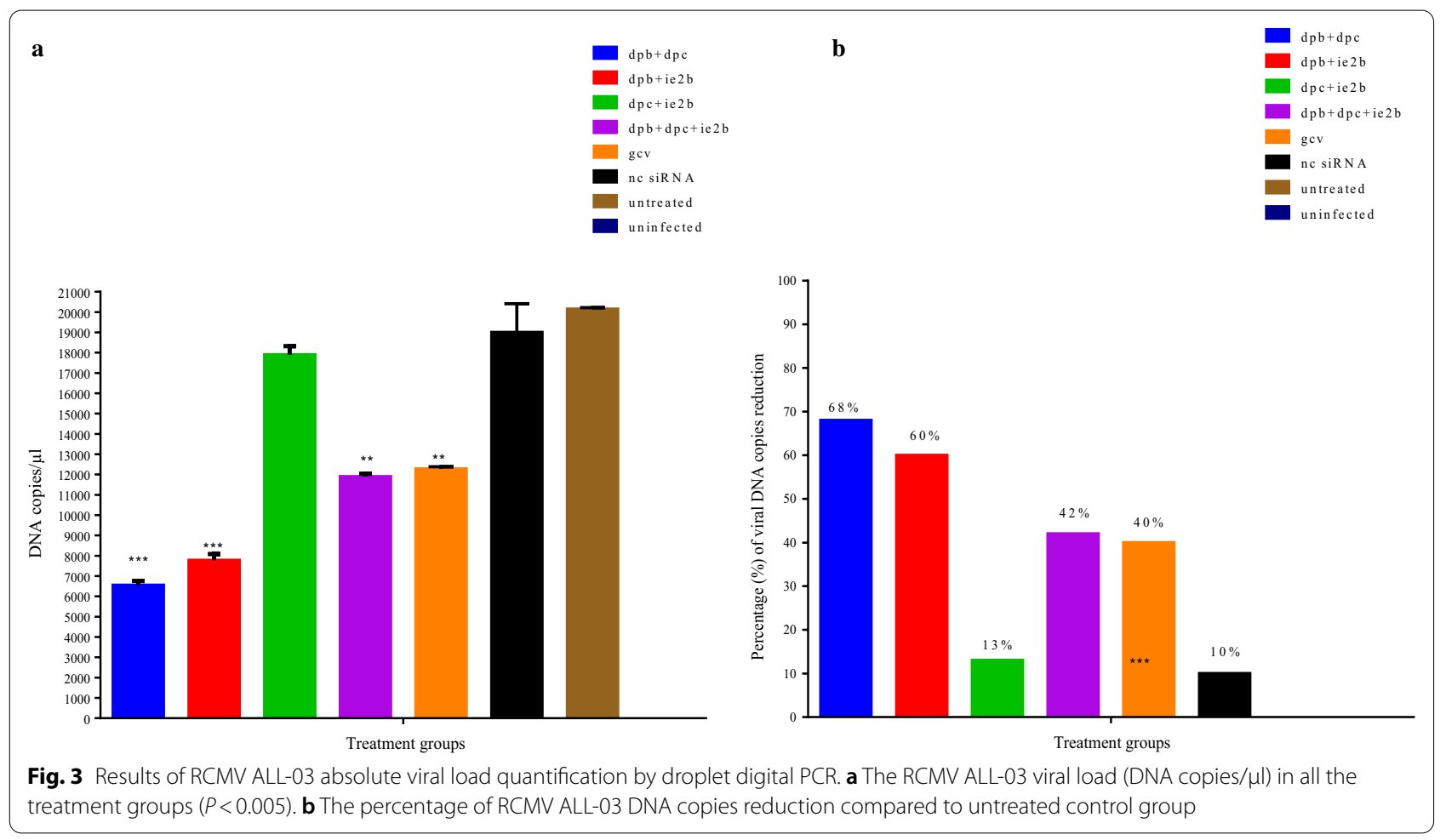

copies $/ \mu$ l) with $40 \%$ of efficiency. Only $2 \%$ of difference in DNA copies reduction percentage was encountered between $\mathrm{dpb}+\mathrm{dpc}+\mathrm{ie} 2 \mathrm{~b}$ and GCV treatment groups. Overall, the percentage of viral reduction was apparently moderate for double and triple combination siRNAs and interestingly, triple siRNAs combination displayed lesser inhibition rate than double combination $(\mathrm{dpb}+\mathrm{dpc}$ and $\mathrm{dpb}+\mathrm{ie} 2 \mathrm{~b})$. On the other hand, untreated control group is having high number of viral particles $(20,200$ copies/ $\mu \mathrm{l})$ due to the absence of any form of treatment.

\section{Antiviral screening using CPE rate development}

To study the CPE rate of RCMV ALL-03 in combination siRNAs treated and non-treated groups, REF cells were transfected with 300 pmol combination siRNAs followed by viral infection, subsequently the cells were monitored for morphological changes at day 14 . Cytopathic effect is a reliable method to monitor the structural changes of host cells resulted from CMV invasion and propagation. There are distinct differences between CMV infected and non-infected groups. Normal cells retain their fibroblast shape, no plaque formation and tightly stuck to the plate up to day 14 (Fig. 4b). In contrast, the cells infected with RCMV ALL-03 exhibited evident morphological changes, starting from cell ballooning, cytoplasmic extension, shape changed to more elongated and finally forming plaque by detaching from flask. The continuation of plaque expands and achieves advanced CPE where most of the cells died and detach from the flask as shown in Fig. 4a. In order to assess the effectivity of combination siRNAs, all the treated cells were examined at day 14 and the rate of CPE development was recorded. As expected, all the combination siRNAs showed to protecting cells from RCMV ALL-03, however, the protection degree was differing from one and another. Out of four combinations, $d p b+d p c$ shown to be most potent combination siRNAs where least rate of CPE was recorded (Fig. 5a). At day 14, 300 pmol of $\mathrm{dpb}+\mathrm{dpc}$ was found to starting CPE with cell ballooning indication as showed in same figure. In comparison, negative control siRNA and virus control cells started to exhibit significant advanced CPE formation at day 14 . Followed by $d p b+d p c, d p b+i e 2 b$ and $\mathrm{dpb}+\mathrm{dpc}+\mathrm{ie} 2 \mathrm{~b}$ showed a good inhibition of CPE at day 14 (Figs. 5 and 6). Contrary to expectations, the results did not show a constant finding in all the siRNAs where $d p c+i e 2 b$ siRNAs are less effective and displayed similar rate of CPE development with negative control siRNA and virus control cells proving their incapability in providing protection for host cells against RCMV ALL-03. These findings showed that triple combination siRNAs are not effective as double combination to inhibit the CPE rate. Thus, this proves the misconception theory of conveying more siRNAs 
$\mathbf{a}$

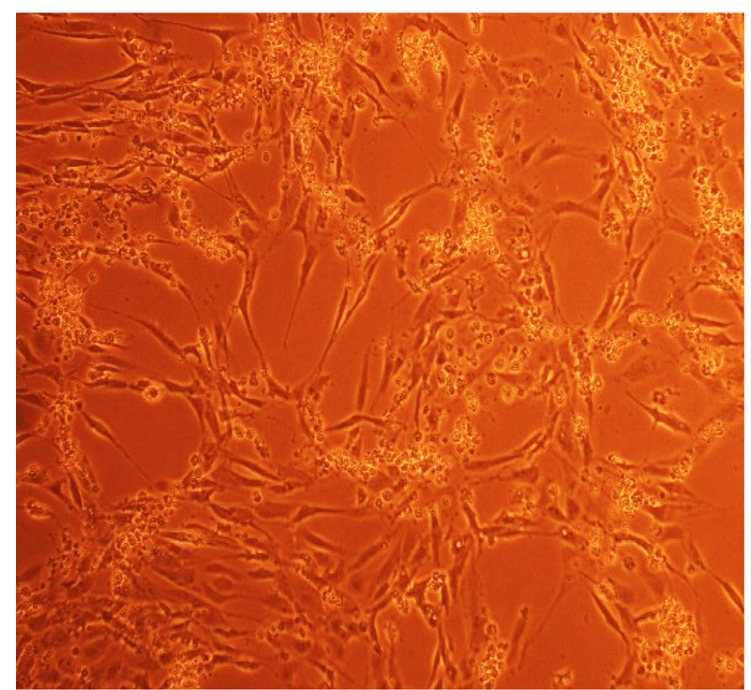

b

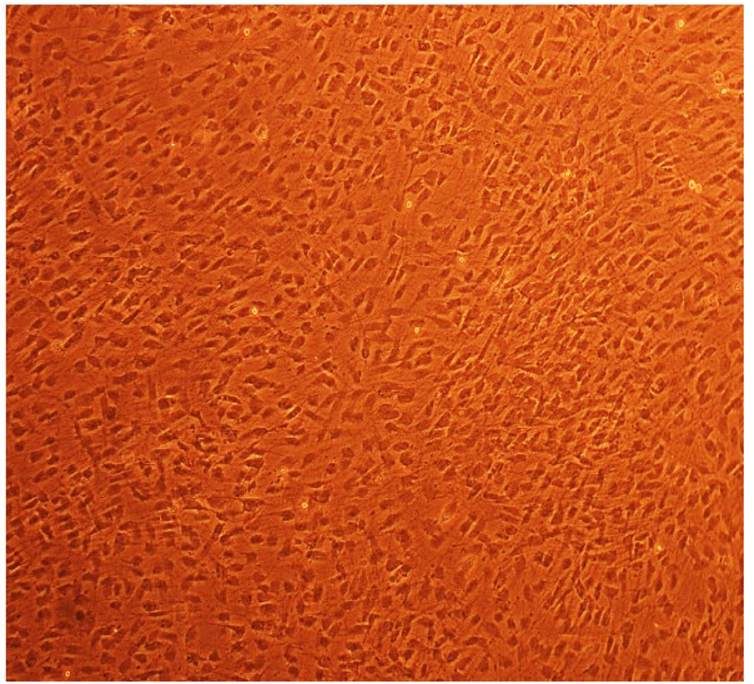

Fig. 4 REF cells were transfected with $d p b+d p c(\mathbf{a})$ and $d p b+i e 2 b(\mathbf{b})$ combination siRNAs followed by RCMV ALL-03 infection. The virus induces specific CPE characterized by rounding of the cells, shrinkage, ballooning and destruction and detachment of cell layers. The cells were visualized at day 14 using an inverted microscope at $10 \times$ magnification

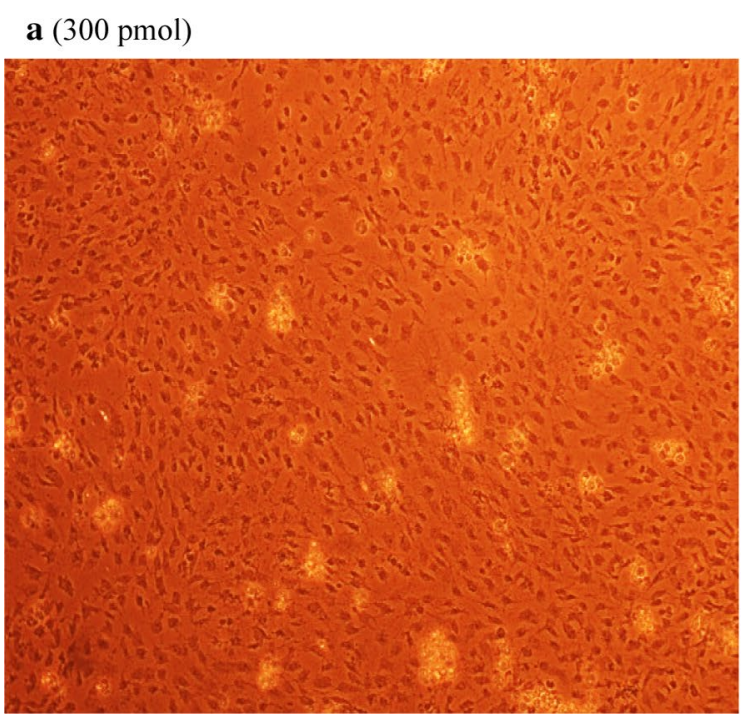

Fig. 5 REF cells were transfected with $d p c+i e 2 b(\mathbf{a})$ and $d p b+d p c+i e 2 b(\mathbf{b})$ combination siRNAs followed by RCMV ALL-03 infection. The virus induces specific CPE characterized by rounding of the cells, shrinkage, ballooning and destruction and detachment of cell layers. The cells were visualized at day 14 using an inverted microscope at $10 \times$ magnification b $(300 \mathrm{pmol})$

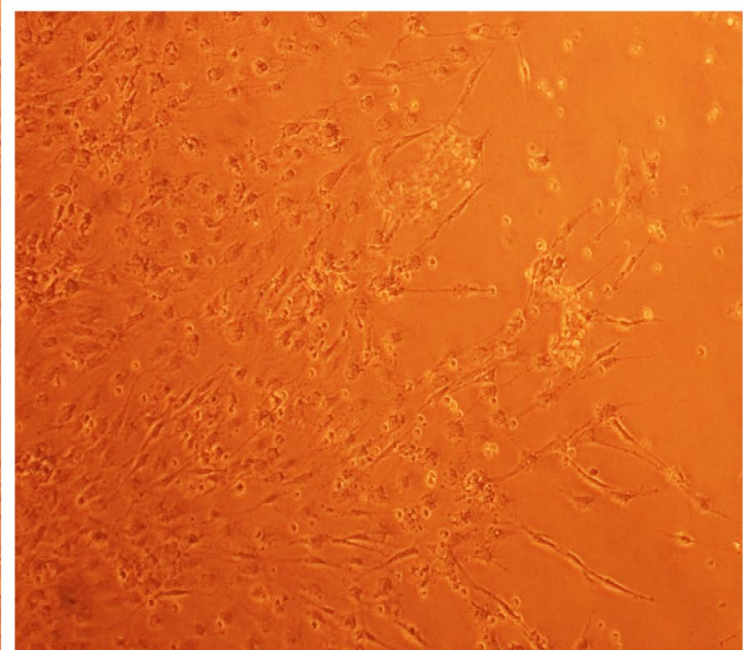

combination providing better viral inhibition rate. The difference in results may be explained by the fact that siRNAs targeting different region of genome having different rate of CPE inhibition effectiveness. Taking into consideration as positive treatment control group, commercial drug GCV exhibited better rate of $\mathrm{CPE}$ inhibition (Fig. 7) compared to other combination siRNAs but lesser efficient than $\mathrm{dpc}+\mathrm{ie} 2 \mathrm{~b}$ siRNAs.

\section{Real time gene expression analysis}

In order to understand more on the role of each combination siRNAs during RCMV ALL-03 infection, all the 
a $(300 \mathrm{pmol})$

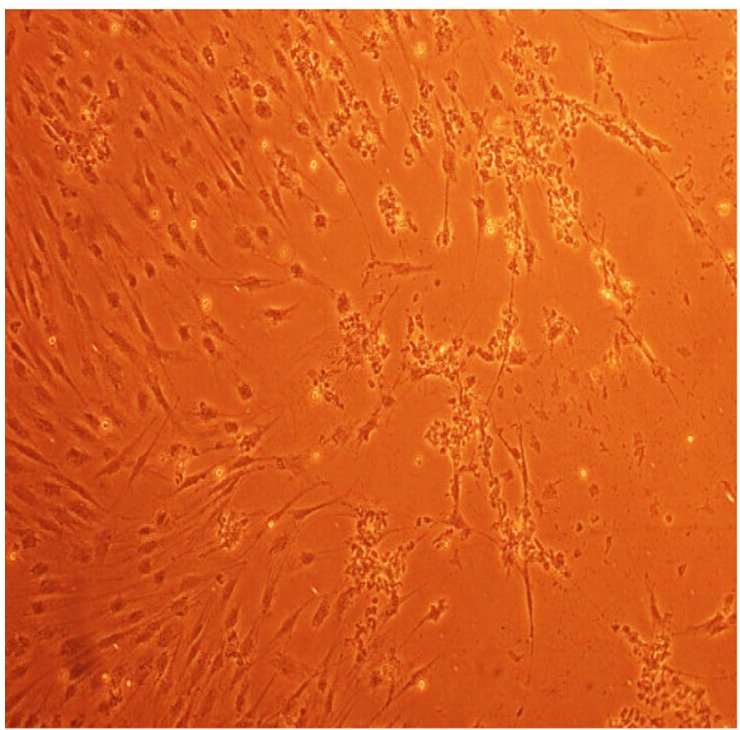

b $(300 \mathrm{pmol})$

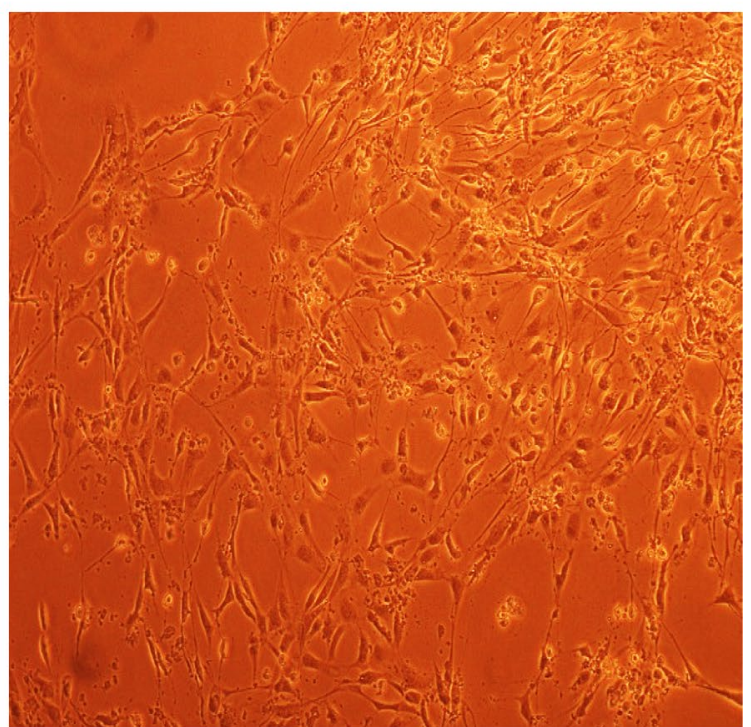

Fig. 6 REF cells were transfected with GCV (a) and negative control siRNA (b) treated followed by RCMV ALL-03 infection. The virus induces specific CPE characterized by rounding of the cells, shrinkage, ballooning and destruction and detachment of cell layers. The cells were visualized at day 14 using an inverted microscope at $10 \times$ magnification

a

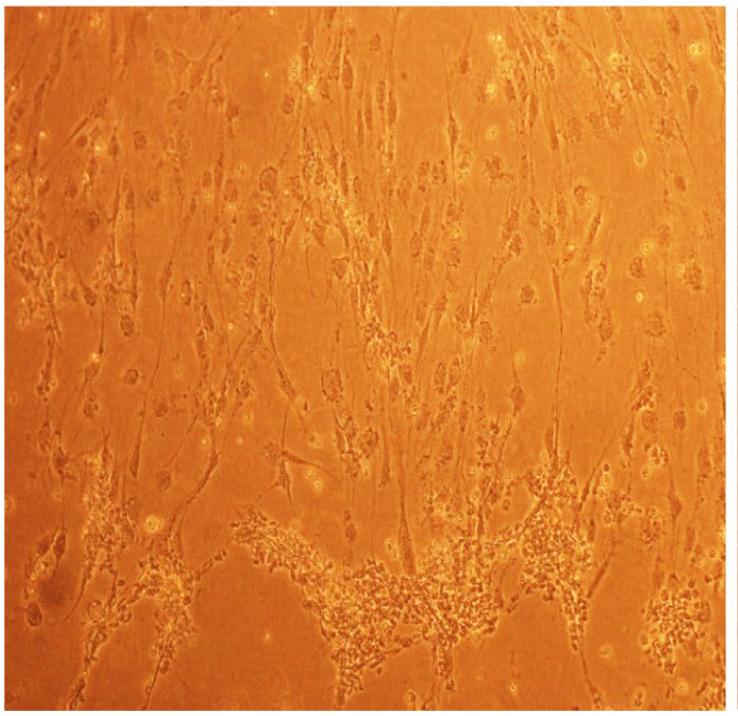

b

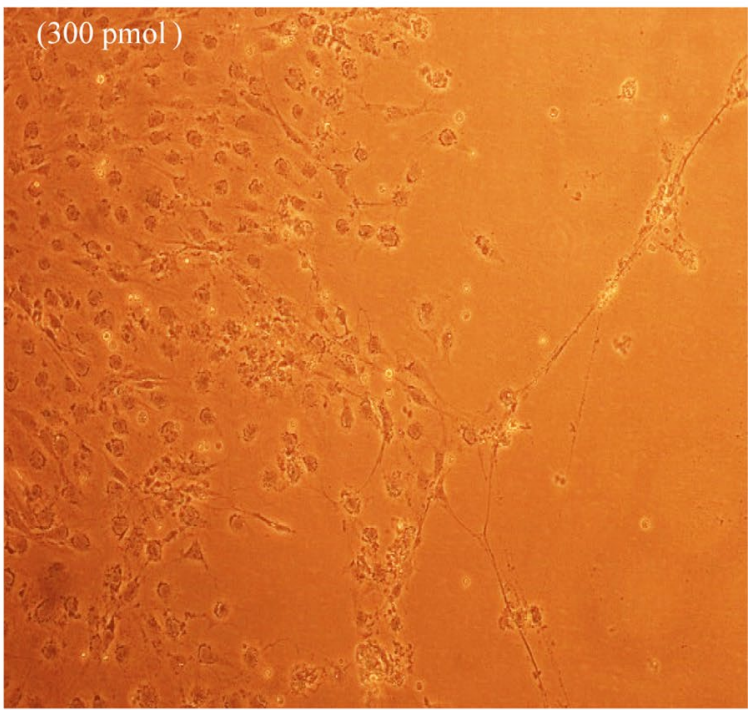

Fig. 7 REF cells were transfected with untreated (a) and uninfected (b) followed by RCMV ALL-03 infection. The virus induces specific CPE characterized by rounding of the cells, shrinkage, ballooning and destruction and detachment of cell layers. The cells were visualized at day 14 using an inverted microscope at $10 \times$ magnification

four combination siRNAs targeting different regions were analyzed individually with specific primers. Overall, the results revealed that each combination siRNAs showed different degree of mRNA reduction with $d p b+d p c, d p b+i e 2 b$ and $d p c+i e 2 b$ showed a greater reduction compared to virus control group (Fig. 8a). SiRNA $d p b+d p c$ found to be very effective by reducing the mRNA expression of DNA polymerase up to $79 \%(P<0.05)$, however $39 \%$ for IE2 gene region. This is mainly due to the siRNAs itself where both siRNAs 
targeting only DNA polymerase and not IE2. Obvious differences were identified for the expressions of both IE2

Table 5 Percentage knockdown of IE2 and DNA polymerase gene expression

\begin{tabular}{|c|c|c|c|}
\hline Treatment & $\Delta \mathrm{Ct}$ expression & $\begin{array}{l}\Delta \Delta C t \\
\text { expression }\end{array}$ & $\%$ knock down \\
\hline \multicolumn{4}{|l|}{$A$} \\
\hline$d p b+d p c$ & $0.094 \pm 0.014$ & $0.660 \pm 0.104$ & 33.90 \\
\hline$d p b+i e 2 b$ & $0.045 \pm 0.001$ & $0.318 \pm 0.008$ & 68.12 \\
\hline$d p c+i e 2 b$ & $0.051 \pm 0.006$ & $0.363 \pm 0.046$ & 63.67 \\
\hline$d p b+d p c+i e 2 b$ & $0.073 \pm 0.008$ & $0.518 \pm 0.058$ & 48.16 \\
\hline GCV & $0.038 \pm 0.001$ & $0.270 \pm 0.006$ & 72.95 \\
\hline nc sirna & $0.107 \pm 0.014$ & $1 \pm 0.100$ & 0 \\
\hline Virus control & $0.142 \pm 0.074$ & $1 \pm 0.518$ & 0 \\
\hline \multicolumn{4}{|l|}{$B$} \\
\hline$d p b+d p c$ & $0.029 \pm 0.005$ & $0.208 \pm 0.041$ & 79.11 \\
\hline$d p b+i e 2 b$ & $0.069 \pm 0.013$ & $0.485 \pm 0.097$ & 51.46 \\
\hline$d p c+i e 2 b$ & $0.044 \pm 0.011$ & $0.315 \pm 0.078$ & 68.41 \\
\hline$d p b+d p c+i e 2 b$ & $0.073 \pm 0.014$ & $0.518 \pm 0.103$ & 48.14 \\
\hline GCV & $0.038 \pm 0.001$ & $0.270 \pm 0.006$ & 72.95 \\
\hline nc sirna & $0.107 \pm 0.014$ & $1 \pm 0.100$ & 0 \\
\hline Virus control & $0.142 \pm 0.074$ & $1 \pm 0.518$ & 0 \\
\hline
\end{tabular}

All the experiments were conducted twice independently in triplicates were presented as results \pm SEM. The results were calculated using delta delta $\mathrm{Ct}$ method and normalized to housekeeping gene, GAPDH mRNA. (A) IE2 and (B) DNA polymerase and DNA polymerase for all the combination siRNAs. Fascinatingly, between the two genes, siRNAs targeting DNA polymerase found to have relatively lower mRNA expression compared to IE2. However, if compared to commercial drug GCV, the combination siRNAs were found to be less potent on inhibiting the IE2 and DNA polymerase expressions as shown in Fig. 8a. In comparison, triple siRNAs combination showed less mRNA inhibition ability on reducing the gene expressions compared to double siRNAs combinations.

\section{Knocking down efficiency}

The silencing effects of siRNAs combination were further transformed to determine the percentage of knockdown efficiency as shown in Table 5 and Fig. 8b. Since the combinations are made up from different siRNAs targeting different regions, each combination were assessed for both IE2 and DNA polymerase genes knock down separately. For IE2 gene region, $d p b+i e 2 b$ and $d p c+i e 2 b$ combinations showed better knocking down efficiencies 63-68\% compared to $\mathrm{dpb}+\mathrm{dpc}$ and triple combination $\mathrm{dpb}+\mathrm{dpc}+\mathrm{ie} 2 \mathrm{~b}(33-48 \%)$ respectively. On the other hand, for DNA poly gene region, all the double siRNAs combination showed better knocking down percentage compared to IE2 region where the range percentage range were between 51 and $79 \%$. The $\mathrm{dpb}+\mathrm{dpc}$ combination targeting DNA polymerase alone showed best level of knocking down among siRNAs followed by $\mathrm{dpc}+\mathrm{ie} 2 \mathrm{~b}$ a

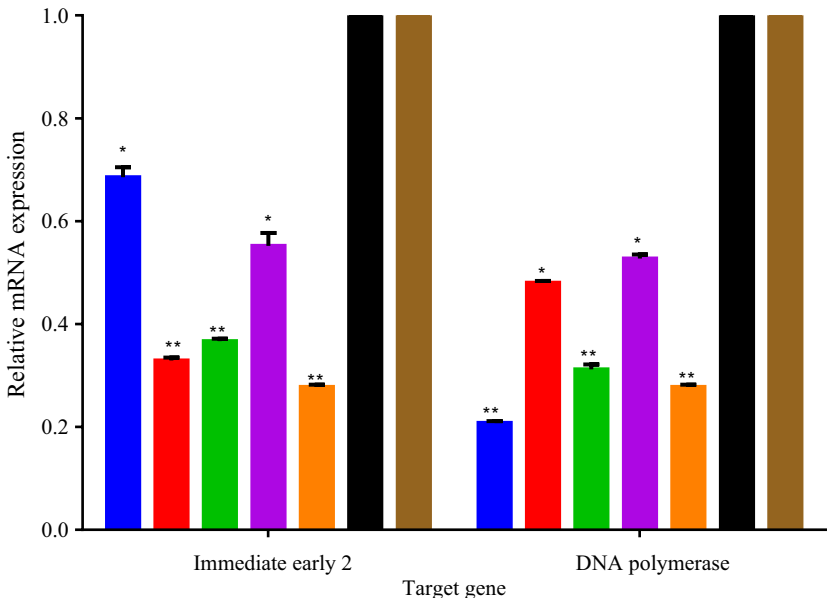

b

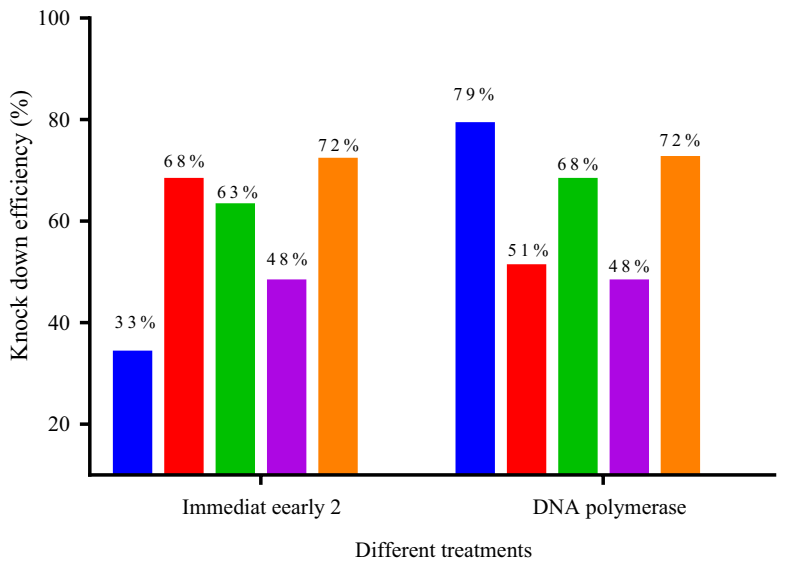

Fig. 8 a Quantification of mRNA expression levels of different treatment groups. b The percentage of knockdown efficiency among siRNA treated and non-treated groups. The data shown are representative of three independent experiments at $P<0.05$ 
and $d p b+i e 2 b$. This clearly shows that the designed siRNAs were found to working best on inhibiting DNA polymerase mRNA expression compared to IE2. Noticeably, triple combinations having 2 DNA poly siRNAs and one IE2 siRNA $(\mathrm{dpb}+\mathrm{dpc}+\mathrm{ie} 2 \mathrm{~b})$ possess lesser potent on reducing the mRNA expression thus having a moderate knocking down efficiency compared to double siRNAs combination. Similar findings were also observed for viral quantification as well CPE rate observation. Therefore, these findings have proven again that more siRNAs in a combination not necessarily possess better knocking down efficiencies of a certain gene. Besides that, GCV still considered as better option in knocking down the both DNA polymerase and IE2 gene regions compared to rest of the siRNAs combination (Table 5). Another important finding was the knockdown efficiency of negative control siRNA. It was found to be zero percent of knocking down efficiency which are similar with virus control group, thus proving its nature as non-target control, which do not carry any impact on virus and host cells. In conclusion, each combinations siRNA hold different degree of gene knock down efficiency with $\mathrm{dpb}+\mathrm{dpc}$ found to be high potent to knock down DNA polymerase gene while $\mathrm{dpb}+\mathrm{ie} 2 \mathrm{~b}$ for IE2 gene.

\section{Sequence identity for resistance of RCMV ALL-03 to siRNA combination treatment}

It is common for viruses to develop resistance against treatment that subjected continuously over a certain period of time. To investigate the tendency to develop resistance via mutation by combination siRNAs treated RCMV ALL-0 were harvested. Then, the extracellular progeny virus was infected repeatedly up to 5 times on combination siRNAs treated REF cells. The final progeny virus was harvested and subjected for DNA extraction. The entire extracted DNA were sequenced by Sanger sequencer platform to identify any possible mutation occurrence and compared with stock RCMV ALL-03 solution using Clustal Omega online software system. For every combination siRNAs treatment, every region involved by the particular individual siRNA was sequenced to obtain all the possible occurrence of mutation. Remarkably, no any mutation was observed for all the siRNAs treated regions thus, proving the ability of designed siRNAs to not developing or delayed the development of siRNAs resistance by RCMV ALL-03. Currently, 5 passages of siRNA treated RCMV ALL-03 were sequenced and more passages needed to be sequenced in future to identify any possible mutations. Since RCMV ALL-03 is double stranded DNA virus, it was expected that the rate of mutation occurrence is extremely lower than RNA viruses which having higher rate of mutation incidence. This statement was supported by findings of this study where siRNAs treated RCMV ALL-03 having $100 \%$ sequence homology with stock of virus (progeny virus without siRNAs treated) proving the lower rate of mutation existence. The detailed information of aligned sequences for each siRNA treated regions compared with stock viruses were portrayed in Fig. 9.

\section{Discussion}

While no approved vaccine or effective therapeutic treatment for CMV, great efforts on research are being made to treat the virus infection by different strategies [37-39]. The effort of making suitable vaccine for CMV started on early 2000 as reported by current National Academy of Medicine United States on the publication of a vaccine priority document [40]. Fascinatingly, CMV was given highest priority on the list and many strategies were implied to develop a suitable one by many biotechnology companies [41, 42]. Unfortunately, effective vaccines are still lacking and haven't approved any by FDA. During the search of effective treatment for CMV, idea of controlling the disease by means of inhibiting virus replication and gene expression by combinations of two and more siRNAs had been explored in this study. Combination therapies have been tested before targeting other viral infections such as influenza, coronavirus, respiratory syncytial virus, hepatitis $B \& C$, vaccinia virus $[23,25,43-46]$. It was hypothesized that targeting two different genes simultaneously could silence the expression of crucial viral genes thus; act as an antiviral therapy against CMV. There are many reasons to pick siRNA as a choice of potential treatment against CMV. First, they are easy to design and cheap to be produced [47]. Next, they are highly specific which can target almost any viral or cellular gene, and their stability can be increased by lyophilization [48]. An additional advantage was they can be delivered in combinations with many siRNAs or with other drugs targeting distinct regions in the same or different genes [46]. Undoubtedly, the mode of treatment action can be expanded by limiting the emergence of treatment resistance candidates [25]. Therefore, all these factors fueling up siRNA research and their successive clinical trials had increased remarkably in recent years [49-51].

Most of the treatments works fine on early stages found to be ineffective over certain period of time. This is due to the capability of viruses to develop resistance in order to escape the attack from antiviral therapies [52]. To resolve this, combination of siRNAs targeting similar or different gene region became popular approach of gene therapy. In detail, they could cleave multiple sites of mRNA which are troublesome for the target to get repaired. Silencing different crucial gene regions at a same time was expected to prevent the emergence of resistant viruses by lowering 


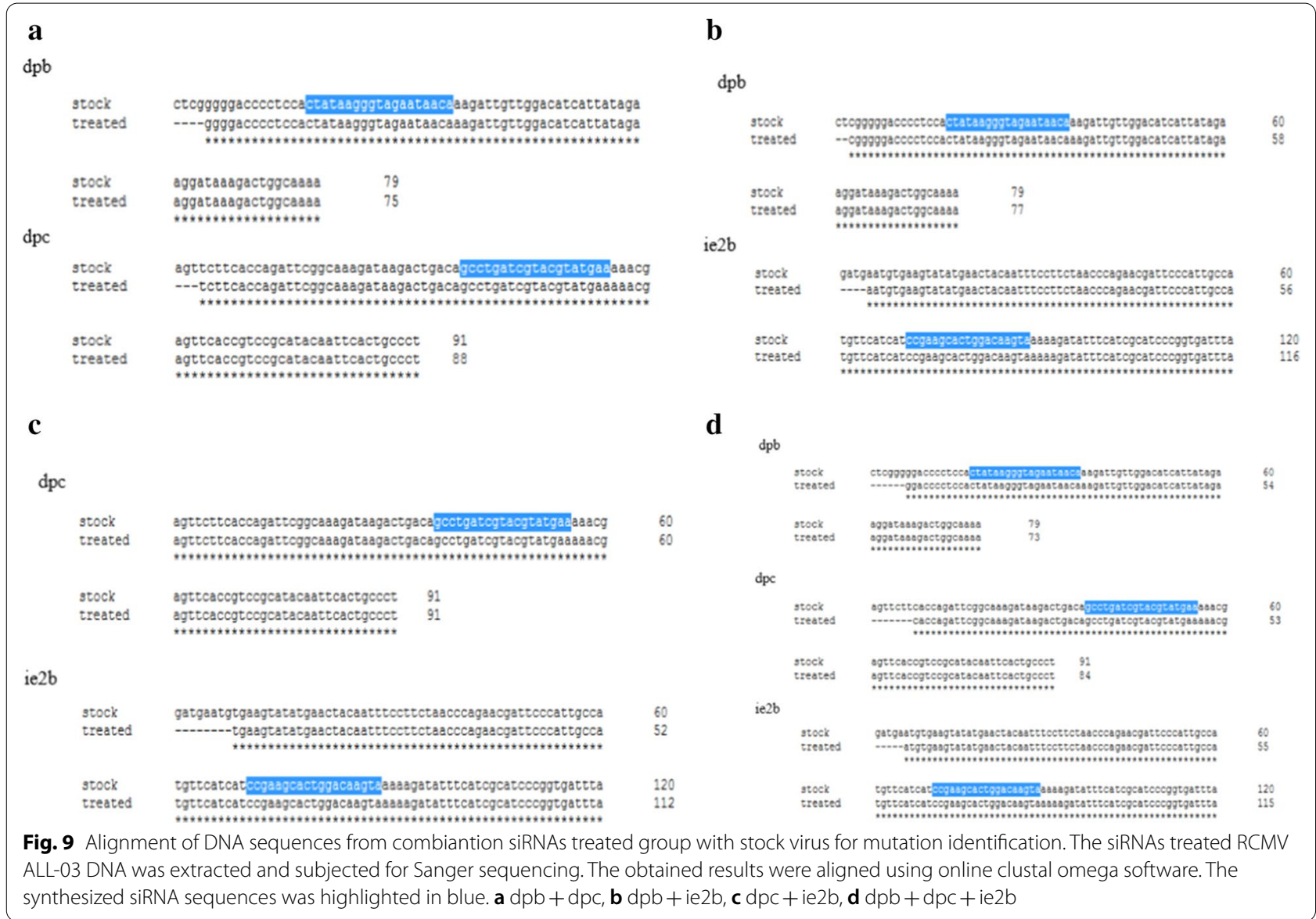

the possibilities of multiple mutation occurrences [12]. The effects of siRNAs could be enhanced by producing combinations pattern which can open a new window on gene therapeutics field. Therefore, the primary aim of this study is to investigate the suitability of combination of siRNAs acting as anti-CMV therapy in a proof of concept study. Although siRNA possess many advantages, unfortunately, the issue of siRNA's off target effects still remain to be addressed and to deal with. Cytotoxicity assay was performed to rule out any combinations that having detrimental effects on the REF cell viability. This is because introducing foreign particles could elevate the level of cytotoxicity of cells which may end up in cell death. Unhealthy or dead cells are not able to sustain the virus production thus, can affects the results of siRNA effectivity [30]. Therefore, before the commencement of combinations siRNA effectivity assay, the cytotoxicity levels of the combinations were determined. The results displayed that these combinations siRNA except $\mathrm{dpb}+\mathrm{dpc}+\mathrm{ie} 2 \mathrm{~b}$ do not seem to induce a significant cytotoxicity level $(P<0.05)$ even at high concentration $(300 \mathrm{pmol})$ in different time points. However, the cell viability for all the siRNAs was found to be constantly decreasing slightly over time. Two siRNA combinations $(\mathrm{dpb}+\mathrm{dpc}, \mathrm{dpb}+\mathrm{ie} 2 \mathrm{~b}$ and $d p c+i e 2 b)$ with each 150 pmol were found to be safe where cell viability was more than $70 \%$ at $72 \mathrm{~h}$ at high concentration (final $300 \mathrm{pmol}$ ). As expected, lower concentration starts from $25 \mathrm{pmol}$ (each $12.5 \mathrm{pmol}$ ) to $3 \mathrm{pmol}$ (each $1.5 \mathrm{pmol}$ ) was observed to have more than $90 \%$ of cell viability at 24,48 and $72 \mathrm{~h}$. However, quite high yet tolerable cytotoxicity level of three siRNA combination $(\mathrm{dpb}+\mathrm{dpc}+\mathrm{ie} 2 \mathrm{~b})$ with each $100 \mathrm{pmol}$ was encountered with cell viability of $50 \%$ at $300 \mathrm{pmol}$. Since $50 \%$ of cytotoxicity level is within the tolerable range, the three-siRNA combination $(\mathrm{dpb}+\mathrm{dpc}+\mathrm{ie} 2 \mathrm{~b})$ was included in the subsequent siRNA experiments.

In the present study, combination of siRNAs targeting IE2 and DNA poly gene regions were proven to suppressing the viral gene expression and inhibiting the replication of virus. The four combinations of siRNA targeting same or different target regions of RCMV ALL-03 displayed effective inhibition of viral replication compared to scrambled siRNA, negative control non-targeting siRNA sample. Compared to GCV, a positive control of treatment group, combinations of duplex siRNAs: $\mathrm{dpb}+\mathrm{dpc}, \mathrm{dpb}+\mathrm{ie} 2 \mathrm{~b}$ and $\mathrm{dpc}+\mathrm{ie} 2 \mathrm{~b}$ showed better viral 
inhibition on day 10 and 18 . However, combination of triple siRNAs: $\mathrm{dpb}+\mathrm{dpc}+\mathrm{ie} 2 \mathrm{~b}$ displayed lesser effective on controlling the viral replication compared to other group of treatments. The obtained results are in agreement with the relative quantification of gene expression by qPCR and also the rate of CPE formation.

Droplet digital PCR was employed to quantify the virus particles present in the treatment groups. Although it has the same role as real-time PCR, but this novel technology is a splendid adaptation of the current PCR being more convenient to be used as it is highly precise and sensitive, hence making results more reliable and easier to reproduce $[53,54]$. More importantly, standard curve is not needed, and the results are interpreted directly by quantifying the droplets having the viral DNA particles. The quantification results revealed that least number of virus particles was observed for $\mathrm{dpb}+\mathrm{dpc}$ treatment group followed by $d p b+d p c$, and $d p b+d p c+i e 2 b$, however, higher number was observed for $\mathrm{dpc}+\mathrm{ie} 2$ treatment group. About $60 \%$ of viral DNA copies reduction was observed for $\mathrm{dpb}+\mathrm{dpc}$ and $\mathrm{dpb}+\mathrm{ie} 2 \mathrm{~b}$ while $42 \%$ for $\mathrm{dpb}+\mathrm{dpc}+\mathrm{ie} 2 \mathrm{~b}$ treatment group. Sadly, only $13 \%$ of viral DNA copies were reduced for $d p c+i e 2 b$ presenting the least effective treatment group. From the detailed analysis, combination of siRNAs having dpb siRNA was found to perform better on virus inhibition rate compared to $\mathrm{dpc}$ and ie $2 \mathrm{~b}$. The obtained results were proving the capability of dpb siRNA on inhibiting viral replication, which established as best siRNA candidate compared to others on individual assessment section previously. Except dpc $+\mathrm{ie} 2 \mathrm{~b}$, other combination of siRNAs portrayed better inhibition on RCMV ALL-03 DNA compared to commercial drug GCV, which served as a positive control for treatment group. Thus, this justifies the need of alternate gene therapy treatment to control the CMV disease more effectively.

Naturally, hosts have many mechanisms to alert their immune system and activating the pathways to block the production of new progeny virus from spreading to other uninfected cells upon infection. To serve the purpose, apoptosis, is an innate cellular defense mechanism responsible to promote programmed cell death, consequently preventing the persistent infection. Apoptosis analysis revealed that combination siRNAs treated group shows a good number of early apoptosis compared to late apoptosis and necrosis cells of untreated control group. Out of four combinations of siRNAs, $\mathrm{dpb}+\mathrm{dpc}$ have significant number of viable and early apoptotic cells compared to late apoptotic cells. Targeting DNA polymerase, $\mathrm{dpb}+\mathrm{dpc}$ combination has successfully inhibiting the virus replication, thus blocking its capacity to suppress the apoptosis pathway. On the other hand, the other three combination siRNAs groups have similar pattern of results where most of the cells are accumulated on early apoptotic cells. No cells were identified on necrotic phase. As expected, majority of cells were observed under late apoptotic phase for negative control siRNA and untreated groups. Therefore, the combinations treatment proving the effectivity to suppresses the growth of RCMV ALL-03 which indirectly suppresses the apoptosis blocking pathway $[55,56]$. Probably, combination siRNAs have good synergetic effect on maintaining the health of host cells.

Few observations were noticed where combination of siRNAs containing ie2b showed reduce level of IE2 gene expression compared to DNA poly. On the other hand, siRNAs containing $\mathrm{dpb}$ and dpc have better mRNA reduction level of DNA poly gene expression compared to IE2. For instance, $\mathrm{dpb}+\mathrm{dpc}$ have high knockdown efficiency on DNA poly gene (79\%) compared to IE2 (33\%) since both candidates are targeting the same gene region. Our combination of siRNAs treatment are in agreement with the findings of individual siRNA where siRNAs targeting DNA poly gene region showed good reduction of mRNA level especially dpb and dpc siRNAs. Next, combination of triple siRNAs: $d p b+d p c+i e 2 b$ showed much lower mRNA level (46-48\%) reduction for both IE2 and DNA poly regions. This clearly showed that duplex siRNA combinations portrayed better inhibition rate of gene expression compared to triple siRNAs combination. The concept of more siRNAs targeting different regions could effectively inhibit virus replication and gene expression seems to be unworkable in our experiments targeting RCMV ALL-03.

Replication of virus in cell culture can be identified from distinctive morphologic changes of REF cell line designated as cytopathic effect also known as CPE [30]. Cytopathic action is commonly to giving us a clue whether the infectivity of virus is related to synthesis of infectious or noninfectious of virus particles. Thus, this can be a preliminary indicator for the RCMV ALL-03 identification purpose. The CPE analysis was carried out on day 14 pi. This is because approximately, it takes 8 to 10 days for CPE to starts and 90\% CPE can be observed by day 14 , as an agreement with CMV cell culture observation Loh et al. [30]. Lesser CPE rate was observed for $\mathrm{dpb}+\mathrm{dpc}$ siRNAs treated group. The cells were started to enlarge, called as ballooning, which are very much better than the CPE conditions of GCV, negative control and untreated groups. Next, $\mathrm{dpb}+\mathrm{ie} 2 \mathrm{~b}$ and $\mathrm{dpc}+\mathrm{ie} 2 \mathrm{~b}$ combinations were displayed similar pattern of CPE with GCV control group, where plaques can be seen clearly due to the de-attachment of the REF cells caused by RCMV ALL-03 growth progression. Nevertheless, $\mathrm{dpb}+\mathrm{dpc}+\mathrm{ie} 2 \mathrm{~b}$ combinations showed to be less prominent to inhibit viral CPE rate where majority of the cells 
were infected, and the plaques are expanding bigger. Surprisingly, the CPE rate was about similar with untreated control group.

Achieving an effective antiviral therapy is much depended on low probability of drug resistance mutant development by an organism [57]. To identify the effects of custom designed combination of siRNAs effects on RCMV ALL-3 genome, the targeted region was sequenced and compared with stock virus. Remarkably, at 5 round of multiple siRNAs treatment, no any significant mutation was observed compared to original stock. This experiment does convey an important message regarding the importance of siRNA design approach. Specific siRNAs targeting highly conserved regions are capable to prevent or reduce the occurrence of mutant which can turn off the inhibitory effect of introduced siRNAs. Besides that, RCMV ALL-03 replication have been reduced by combination siRNAs treatment which indirectly limiting the likelihood of mutation occurrence by inhibiting the growth of virus population carrying the mutated gene for infection. In addition, CMV is double stranded DNA virus where the rate of mutation occurrence is low compared to other RNA viruses. Therefore, future studies on mutation identification need to be carried out at higher multiple round of siRNAs treatment.

In terms of performance, combination siRNAs containing IE2b especially $\mathrm{dpb}+\mathrm{ie} 2 \mathrm{~b}$ and $\mathrm{dpc}+\mathrm{ie} 2 \mathrm{~b}$ combinations displayed less efficient than $\mathrm{dpb}+\mathrm{dpc}$ on inhibiting RCMV ALL-03 replication and gene expression. IE is the first ever gene to be transcribed after CMV infection. The IE products generated by differential splicing subsequently, will transactivate early genes. Initially, it was expected that silencing IE gene region particularly IE2 could stop the activation of other genes. Unfortunately, different scenario was observed where minimal expression of IE may adequate to turn on other genes, hence, progressing towards viral replication. This statement was supported by qPCR where high percentage of IE2 knockdown siRNAs yet expressing DNA polymerase and producing viral progeny.

Overall, according to the results obtained, combination of siRNAs found to possess antiviral activity against RCMV ALL-03, however, less impressive compared to highly efficient individual siRNAs when applied at same total concentration at 300 pmol. Unfortunately, the synergistic effects of combination siRNAs could not compete with the effectiveness of individual siRNAs from all the gathered results of virus titration, virus particles quantification, mRNA level investigation, CPE rate analysis and status of cell viabilities. The exact answer for the obtained results are unclear however, there are few reasons to explain the situation. First, there are higher chances for the siRNAs to compete each other for the association with RISC protein, which might have negative effects on each other's synergistic activity [58]. Second, the proportion of each siRNA to get delivered into the cells is yet unclear even though the siRNAs were mixed at equal concentration. May one can get transported into the cells more often compared to other which could lead for the failure of synergistic effects. Next, the properties of siRNAs are varying among one another due to the different sequence composition, GC content, stability and affinity to bind the RISC protein [59]. More successful binding can direct the RISC to target so that more frequent cleavage to occur at particular target. On the other hand, least successful siRNAs binding to RISC would have lesser cleavage frequency in turn having lesser effectiveness. Thus, the individual characteristics of siRNA could be superior to another which the stronger siRNA have more silencing effects compared to weaker one [60].

Some studies have tried combination siRNAs for the purpose of silencing viral gene target and cellular host factor which support the virus replication. For example, another study has been conducted and proved that $\mathrm{HCV}$ replication was inhibited pronouncedly by introducing siRNAs which are targeting RNA dependent RNA polymerase viral gene as well La autoantigen of cellular factor [23]. Therefore, similar perspective of experiment can be conducted for RCMV ALL-03 in future to maximize the efficiency of combination siRNAs on inhibiting the virus replication and gene expression. However, one needs to be more careful on choosing the cellular factor where the effects of silencing don't bring any detrimental harm for the host [61]. Taken all these together, combinations siRNAs application found to be beneficial in inhibiting the virus replication and more research need to be conducted to enhance the efficiency. Despite human viruses, this system can be utilized for animal viruses which having an unbearable impact on poultry industries due to virus infections [60,62]. Apart from that, this combinatorial siRNAs approach could replace as an alternate treatment especially for plant-based vaccines which encountering difficulties during production [63].

\section{Conclusion}

This is the first study initiated to investigate the effectiveness of siRNA combinations to inhibit Malaysian isolate CMV. The combinations were formulated based on the individual performance on inhibiting RCMV ALL-03. The results markedly inhibited by viral genomic DNA, gene expression and CMV replication in vitro, however, the findings are varying according to the combinations. The siRNA combinations containing dpb siRNA showed better rate of viral inhibition, as similar with the individual characteristics. Overall, combinations having two siRNAs showed promising results that the triple siRNA 
combination. Interestingly, no any mutation occurrence was encountered among the treated groups thus highlighting its feasibility to be used as treatment option in future.

\section{Supplementary information}

Supplementary information accompanies this paper at https://doi. org/10.1186/s12985-020-01436-5.

Additional file 1: Figure S1. Standard curve and amplification curve of the siRNAs and GAPDH were determined from tenfold serial dilution of RNA isolated from treated cells. Figure S2. The cytotoxicity of combinations siRNA targeting RCMV ALL-03 and negative control siRNA in REF cells. Cells were transfected with lipofectamine 3000 and siRNA complex, which were prepared in final concentration of $300 \mathrm{pmol}$ of siRNA and incubated for $6 \mathrm{~h}$ and an additional of $24 / 48 / 72 \mathrm{~h}$ at $37^{\circ} \mathrm{C}$. The cellular viability was measured by MTT assay. Each treatment was performed in triplicate and repeated in two independent experiments. Results represent Mean \pm Standard deviation. Figure S3. Gating references used for unstained, PI and FITC apoptosis analysis using flow cytometry. Figure S4. 1D ddPCR analysis plot shows detection of RCMV ALL-03 DNA in siRNA treated and non-treated groups. Each sample was partitioned into an average of 10,000 droplets per well and replicated in two wells. The droplet counts for positive (blue) and negative (gray) from all replicated wells were combined to yield a "merged" well. A fluorescence amplitude value $>1176$ (pink line) was considered to be a positive droplet.

\section{Abbreviations}

siRNA: Small interfering RNA; CMV: Cytomegalovirus; RCMV: Rat Cytomegalovirus; IE2: Immediate early 2; pmol: Picomole; CPE: Cytopathic effect; ddPCR: Droplet digital PCR.

\section{Acknowledgements}

Not applicable.

\section{Authors' contributions}

The authors were hereby given a declaration that this work was done by all of them named in this paper and all liabilities pertaining to claims relating to the content of this article will be borne by them. KNB, AAA and JAB conceived the idea, participates in data collection and run the test. CACA, FFAJ, MMN and MLMA participated in conceptualization of the idea, study design, consultation, review, and editing of paper, KNB, CACA, FFAJ, MMN and MLMA involved in results interpretation as well as preparation of the final manuscript draft. All authors read and approved the final manuscript.

\section{Funding}

This study was funded by Ministry of Higher Education Malaysia Vot no: 5424930 and IPS Universiti Putra Malaysia Vot No.: 9616900.

\section{Availability of data and materials}

All data generated or analyzed during this study are included in this manuscript.

\section{Ethical statement}

The study does not contain any experiments involving human or animal participation, and all experiments in this study are in compliance with ethical standards for research.

\section{Consent for publication}

Not applicable.

\section{Competing interests}

The authors declare that they have no any conflicts of interest regarding the publication the publication of this article.

\section{Author details}

${ }^{1}$ Department of Pathology and Microbiology, Faculty of Veterinary Medicine, University Putra Malaysia, Selangor, Malaysia. ${ }^{2}$ Department of Microbiology, Faculty of Applied Science, Taiz University, Taiz, Yemen. ${ }^{3}$ Department of Medical Laboratory Science, Faculty of Allied Health Sciences, Microbiology Unit, Bayero University, Kano, Nigeria. ${ }^{4}$ Department of Veterinary Clinical Studies, Faculty of Veterinary Medicine, Universiti Putra Malaysia, Selangor, Malaysia. ${ }^{5}$ Department of Physics, Faculty of Science, Universiti Putra Malaysia, Selangor, Malaysia.

Received: 21 July 2020 Accepted: 16 October 2020

Published online: 27 October 2020

\section{References}

1. AshwaqAhmed A, KrishnanNair B, JamiluAbubakar B, FaezFirdausJesse A, ZeenatulAllaudin N, Rasedee A, et al. Cytomegalovirus replication steps and the actions of antiviral drugs. Anti-Infect Agents. 2018;16(2):80-95.

2. Manicklal S, Emery VC, Lazzarotto T, Boppana SB, Gupta RK. The "silent" global burden of congenital cytomegalovirus. Clin Microbiol Rev. 2013;26(1):86-102.

3. Lachmann R, Loenenbach A, Waterboer T, Brenner N, Pawlita M, Michel A, et al. Cytomegalovirus (CMV) seroprevalence in the adult population of Germany. PLOS ONE. 2018;13(7):e0200267-e.

4. Wurzer P, Guillory A, Parvizi D, Clayton RP, Branski LK, Kamolz L-P, et al. Human herpes viruses in burn patients: a systematic review. Burns. 2017;43(1):25-33.

5. Vancíková Z, Dvorák P. Cytomegalovirus infection in immunocompetent and immunocompromised individuals - a review. Curr Drug Targets Immune Endocr Metabol Disord. 2001;1(2):179-87.

6. Kim CS. Congenital and perinatal cytomegalovirus infection. Korean J Pediatr. 2010;53:14.

7. Malm G, Engman M-L. Congenital cytomegalovirus infections. Sem Fetal Neonatal Med. 2007;12(3):154-9.

8. Fire A, Xu S, Montgomery MK, Kostas SA, Driver SE, Mello CC. Potent and specific genetic interference by double-stranded RNA in Caenorhabditis elegans. Nature. 1998;391(6669):806-11.

9. Dana H, Chalbatani GM, Mahmoodzadeh $H$, Karimloo R, Rezaiean O, Moradzadeh A, et al. Molecular mechanisms and biological functions of siRNA. Int J Biomed Sci. 2017:13(2):48-57.

10. Ahmadzada T, Reid G, McKenzie DR. Fundamentals of siRNA and miRNA therapeutics and a review of targeted nanoparticle delivery systems in breast cancer. Biophys Rev. 2018;10(1):69-86.

11. Barik S. siRNA for influenza therapy. Viruses. 2010;2(7):1448-57.

12. Levanova A, Poranen MM. RNA interference as a prospective tool for the control of human viral infections. Front Microbiol. 2018;9:2151.

13. Chen J, Li F, Xu Y, Zhang W, Hu Y, Fu Y, et al. Cholesterol modification of SDF-1-specific siRNA enables therapeutic targeting of angiogenesis through Akt pathway inhibition. Exp Eye Res. 2019;184:64-71.

14. Flisiak R, Jaroszewicz J, Łucejko M. siRNA drug development against hepatitis B virus infection. Expert Opin Biol Ther. 2018;18(6):609-17.

15. Togtema M, Jackson R, Grochowski J, Villa PL, Mellerup M, Chattopadhyaya J, et al. Synthetic siRNA targeting human papillomavirus 16 E6: a perspective on in vitro nanotherapeutic approaches. Nanomedicine. 2018;13(4):455-74.

16. Elbashir SM, Harborth J, Lendeckel W, Yalcin A, Weber K, Tuschl T. Duplexes of 21-nucleotide RNAs mediate RNA interference in cultured mammalian cells. Nature. 2001;411(6836):494-8.

17. Qureshi A, Tantray VG, Kirmani AR, Ahangar AG. A review on current status of antiviral siRNA. Rev Med Virol. 2018;28(4):e1976.

18. Grimm D, Kay MA. Combinatorial RNAi: a winning strategy for the race against evolving targets? Mol Ther J Am Soc Gene Ther. 2007;15(5):878-88.

19. Boden D, Pusch O, Lee F, Tucker L, Ramratnam B. Human immunodeficiency virus type 1 escape from RNA interference. J Virol. 2003;77(21):11531-5.

20. Gitlin L, Stone JK, Andino R. Poliovirus escape from RNA Interference: short Interfering RNA-target recognition and implications for therapeutic approaches. J Virol. 2005;79(2):1027-35. 
21. Wilson JA, Richardson CD. Hepatitis C virus replicons escape RNA interference induced by a short interfering RNA directed against the NS5b coding region. J Virol. 2005;79(11):7050-8.

22. Zhang $X$, Zheng $H$, Xu M, Zhou Y, Li X, Yang F, et al. Evaluation of a combinatorial RNAi lentivirus vector targeting foot-and-mouth disease virus in vitro and in vivo. Mol Med Rep. 2015;12(5):6672-8.

23. Mandal A, Ganta KK, Chaubey B. Combinations of siRNAs against La autoantigen with NS5B or hVAP-A have additive effect on inhibition of HCV replication. Hepatitis Res Treat. 2016. https://doi. org/10.1155/2016/9671031.

24. Braga ACS, Carneiro BM, Batista MN, Akinaga MM, Rahal P. Inhibition of hepatitis $C$ virus using siRNA targeted to the virus and Hsp90. Cell Stress Chaperones. 2017;22(1):113-22.

25. McDonagh P, Sheehy PA, Norris JM. Combination siRNA therapy against feline coronavirus can delay the emergence of antiviral resistance in vitro. Vet Microbiol. 2015;176(1-2):10-8.

26. Abdullah JM, Ahmad F, Ahmad KA, Ghazali MM, Jaafar H, Ideris A, et al. Molecular genetic analysis of BAX and cyclin D1 genes in patients with malignant glioma. Neurol Res. 2007;29(3):239-42.

27. ShenNi L, Allaudin ZN, MohdLila MA, Othman AM, Othman F. Selective apoptosis induction in MCF-7 cell line by truncated minimal functional region of apoptin. BMC Cancer. 2013;13(1):488.

28. Hani H, Ibrahim TA, Othman AM, Lila MA, Allaudin ZN. Isolation, density purification, and in vitro culture maintenance of functional caprine islets of Langerhans as an alternative islet source for diabetes study. Xenotransplantation. 2010;17(6):469-80.

29. Vakhshiteh F, Allaudin ZN, MohdLila MA, Hani H. Size-related assessment on viability and insulin secretion of caprine islets in vitro. Xenotransplantation. 2013;20(2):82-8.

30. Loh HS, Mohd-Azmi ML, Lai KY, Sheikh-Omar AR, Zamri-Saad M. Characterization of a novel rat cytomegalovirus (RCMV) infecting placentauterus of Rattus rattus diardii. Arch Virol. 2003;148(12):2353-67.

31. Loh H-S, Mohd-Lila M-A, Abdul-Rahman S-O, Kiew L-J. Pathogenesis and vertical transmission of a transplacental rat cytomegalovirus. Virol J. 2006;3(1):42.

32. Balakrishnan KN, Abdullah AA, Camalxaman SN, Quah YW, Abba Y, Hani H, et al. Complete genome sequence of rat cytomegalovirus strain ALL-03 (Malaysian Strain). Genome announcements: American Society for Microbiology; 2015. p. e00451-15.

33. Balakrishnan KN, Abdullah AA, Bala J, Abba Y, Sarah SA, Jesse FFA, et al. Identification and comparison of RCMV ALL 03 open reading frame (ORF) among several different strains of cytomegalovirus worldwide. Infect Genet Evol. 2017;54:81-90.

34. Reed $L$, Muench $H$. A simple method of estimating fifty per cent endpoints. Am J Epidemiol. 1938;27(3):493-7.

35. Bustin SA, Benes V, Garson JA, Hellemans J, Huggett J, Kubista M, et al. The MIQE guidelines: minimum information for publication of quantitative real-time PCR experiments. Clin Chem. 2009;55(4):611-22.

36. Haimes JD, Kelley MA. Demonstration of a $\triangle \triangle \mathrm{Cq}$ calculation method to compute relative gene expression from qPCR data. USA:Thermo Scientific; 2015.

37. Torre-Cisneros J, Aguado JM, Caston JJ, Almenar L, Alonso A, Cantisán S, et al. Management of cytomegalovirus infection in solid organ transplant recipients: SET/GESITRA-SEIMC/REIPI recommendations. Transpl Rev. 2016:30(3):119-43.

38. Schleiss MR, Permar SR, Plotkin SA. Progress toward development of a vaccine against congenital cytomegalovirus infection. Clin Vacc Immunol. 2017a;24(12):e00268-17.

39. Bruminhent J, Razonable RR. Management of cytomegalovirus infection and disease in liver transplant recipients. World J Hepatol. 2014;6(6):370-83.

40. Lawrence RS, Durch JS, Stratton KR. Vaccines for the 21st century: a tool for decisionmaking. New York: National Academies Press; 2001.

41. Plotkin SA, Boppana SB. Vaccination against the human cytomegalovirus. Vaccine. 2019;37(50):7437-42.
42. Schleiss MR, Permar SR, Plotkin SA. Progress toward development of a vaccine against congenital cytomegalovirus infection. Clin Vaccine Immunol. 2017b;24(12):e00268-e317.

43. Martin-Vicente M, Resino S, Martinez I. siRNA-mediated simultaneous regulation of the cellular innate immune response and human respiratory syncytial virus replication. Biomolecules. 2019;9(5):165.

44. Xin X-M, Li G-Q, Jin Y-Y, Zhuang M, Li D. Combination of small interfering RNAs mediates greater suppression on hepatitis B virus cccDNA in HepG2. 2.15 cells. World J Gastroenterol. 2008;14(24):3849.

45. Bian Z, Xiao A, Cao M, Liu M, Liu S, Jiao Y, et al. Anti-HBV efficacy of combined siRNAs targeting viral gene and heat shock cognate 70. Virol J. 2012;9(1):275.

46. Vigne S, Duraffour S, Andrei G, Snoeck R, Garin D, Crance J-M. Inhibition of vaccinia virus replication by two small interfering RNAs targeting B1R and G7L genes and their synergistic combination with cidofovir. Antimicrob Agents Chemother. 2009;53(6):2579-88.

47. Sohail M, Doran G, Riedemann J, Macaulay V, Southern EM. A simple and cost-effective method for producing small interfering RNAs with high efficacy. Nucleic Acids Res. 2003;31(7):e38-e.

48. Gaglione M, Mercurio ME, Potenza N, Mosca N, Russo A, Novellino E, et al. Synthesis and gene silencing properties of siRNAs containing terminal amide linkages. Biomed Res Int. 2014;2014:901617.

49. Potaczek DP, Garn H, Unger SD, Renz H. Antisense molecules: A new class of drugs. J Allergy Clin Immunol. 2016;137(5):1334-46.

50. Saw PE, Song EW. siRNA therapeutics: a clinical reality. Sci China Life Sci. 2019;63:485.

51. Hu B, Weng $Y, X i a X-H$, Liang $X$, Huang $Y$. Clinical advances of siRNA therapeutics. J Gene Med. 2019;21(7):e3097.

52. Setten RL, Rossi JJ, Han S. The current state and future directions of RNAibased therapeutics. Nature Rev Drug Discov. 2019;18(6):421-46.

53. Taylor SC, Laperriere G, Germain H. Droplet Digital PCR versus qPCR for gene expression analysis with low abundant targets: from variable nonsense to publication quality data. Sci Rep. 2017;7(1):2409.

54. Quan P-L, Sauzade M, Brouzes E. dPCR: a technology review. Sensors (Basel). 2018;18(4):1271.

55. Thomson BJ. Viruses and apoptosis. Int J Exp Pathol. 2001:82(2):65-76.

56. Çam M, Handke W, Picard-Maureau M, Brune W. Cytomegaloviruses inhibit Bak- and Bax-mediated apoptosis with two separate viral proteins. Cell Death Differ. 2010;17(4):655-65.

57. Richman DD, Nathanson N. Chapter 20-Antiviral therapy. In: Katze MG, Korth MJ, Law GL, Nathanson N, editors. Viral pathogenesis. 3rd ed. Boston: Academic Press; 2016. p. 271-87.

58. Koller E, Propp S, Murray H, Lima W, Bhat B, Prakash TP, et al. Competition for RISC binding predicts in vitro potency of siRNA. Nucleic Acids Res. 2006;34(16):4467-76.

59. Kurreck J. siRNA efficiency: structure or sequence-that is the question. J Biomed Biotechnol. 2006;2006(4):83757.

60. He F, Han Y, Gong J, Song J, Wang H, Li Y. Predicting siRNA efficacy based on multiple selective siRNA representations and their combination at score level. Sci Rep. 2017;7(1):44836.

61. Xiaofei E, Stadler BM, Debatis M, Wang S, Lu S, Kowalik TF. RNA interference-mediated targeting of human cytomegalovirus immediate-early or early gene products inhibits viral replication with differential effects on cellular functions. J Virol. 2012;86(10):5660-73.

62. Bala JA, Balakrishnan KN, Abdullah AA, Adamu L, Noorzahari MS, May LK, et al. An association of Orf virus infection among sheep and goats with herd health programme in Terengganu state, eastern region of the peninsular Malaysia. BMC Vet Res. 2019;15(1):250.

63. Laere E, Ling APK, Wong YP, Koh RY, Mohd Lila MA, Hussein S. Plant-based vaccines: production and challenges. J Bot. 2016;2016:4928637.

\section{Publisher's Note}

Springer Nature remains neutral with regard to jurisdictional claims in published maps and institutional affiliations. 